\title{
Photoperiodic response in the formation of gametangia of the long-day plant Sphacelaria rigidula (Phaeophyceae)
}

\author{
A. ten Hoopen, S. Bos and A. M. Breeman \\ Department of Marine Biology, Biological Centre, Rijksuniversiteit Groningen, Postbox 14, 9750 AA Haren (Gr.), \\ The Netherlands
}

\begin{abstract}
The effect of daylength and irradiance on the formation of gametangia in the male gametophyte of Sphacelaria rigidula Kütz $(=S$. furcigera Kütz [Prud'homme van Reine 1982]) was investigated. Formation of gametangia was restricted to long-day conditions: in light-dark regimes with $12 \mathrm{~h}$ of light per day or less, no gametangia were formed. In long-day regimes high irradiances caused a suboptimal response, especially near the critical daylength. Interruption of a long dark period with a light break promoted gametangia formation. Light breaks were most effective when given at about the 6th hour of darkness. Nine inductive long-day cycles were required to induce the formation of gametangia, which appeared after ca. $15 \mathrm{~d}$. The plants remained in the induced state only for a very short time. In regimes with very long days and at high irradiance the number of fertile plants decreased after some time, when vigorous vegetative growth started without any further formation of gametangia.
\end{abstract}

\section{INTRODUCTION}

The work of van den Hoek and Flinterman (1968) and that of Colyn and van den Hoek (1971) clearly indicate the importance of daylength and temperature as factors regulating the slightly heteromorphic diplohaplontic life-history of the brown alga Sphacelaria rigidula Kütz. (as S. furcigera Kütz.) At low temperature $\left(12{ }^{\circ} \mathrm{C}\right.$ or less) and long-day conditions, the female gametophyte formed plurilocular macrogametangia. Plurilocular microgametangia were produced by the male gametophyte at the same temperatures, but an influence of daylength could not be clearly established. Zygotes resulting from fusion of the microgametes with the macrogametes developed into diploid sporophytes which formed unilocular sporangia at $4{ }^{\circ} \mathrm{C}$, possibly only on short days. Propagules, the special organs for vegetative reproduction, were formed in all life-history phases at high temperatures $\left(12{ }^{\circ} \mathrm{C}\right.$ or higher $)$ and long-day conditions.

In various Phaeophycean genera an effect of daylength on reproduction has been reported (Lüning, 1980, 1981a; Terry and Moss, 1980). Whether a response to daylength is caused by a photoperiodic mechanism depends on the following criteria (Dring, 1970): (1) Long-day plants respond if the period of uninterrupted darkness in a light-dark cycle of $24 \mathrm{~h}$ is less than a certain critical length. (2) If, in a $24 \mathrm{~h}$ cycle, a long dark period is interrupted by a short light break, the response is promoted in long-day plants. (3) Plants can be induced to respond by a relatively short exposure to cycles of the appropriate daylength, and will then remain in the induced state for some time after their return to a non-inductive daylength. Reports on long-day reactions in algae have been reviewed by Dring (1970) but so far no true photoperiodic responses have been found.

In the present work, an attempt was made to clarify the role of daylength and irradiance on the formation of male gametangia in Sphacelaria rigidula.

\section{MATERIAL AND METHODS}

Uni-algal stock cultures of the isolates used in the investigations of van den Hoek and Flinterman (1968) and Colyn and van den Hoek (1971) were available. The male gametophytes were in a relatively healthy state after they had been maintained for several years at $4{ }^{\circ} \mathrm{C}, 8 \mathrm{~h}$ light each day $(8: \overline{16})$. Male gametophytes were provided with fresh soil extract medium (slightly modified after Breeman [1979]) with half the concen- 
tration of forest soil extract and salts per liter filtered seawater and autoclavation for $10 \mathrm{~min}$ at $110^{\circ} \mathrm{C}$ ). The plants were transferred to $500 \mathrm{ml}$ glass containers at $20{ }^{\circ} \mathrm{C}$, at $30 \pm 10 \mu \operatorname{Ein} \mathrm{m}^{-2} \mathrm{~s}^{-1}, 8: \overline{16}$. In about $2 \mathrm{wk}$ healthily growing cultures were obtained.

From this stock culture, plants were cut into ca. $5 \mathrm{~mm}$ long fragments; these were planted at regular distances on Whatman GF/A $11 \mathrm{~cm}$ glass microfibre filterpaper placed on the bottom of $11 \mathrm{~cm}$ glass Petri dishes. Within a few days the branches had fastened to the microfibre paper (Fig. 1a). The number of plants per Petri dish was ca. 50 (15 to 79 ).

Experiments were conducted in controlled environment incubators (Fridina) at $12{ }^{\circ} \mathrm{C} \pm 1 \mathrm{C}^{\circ}$. At this tem- perature the formation of propagula was mostly suppressed. The culture medium was renewed every fortnight.

In the incubators, four $20 \mathrm{~W}$ Philips TL34 fluorescent tubes provided light. Irradiance was measured with a LICor LI185 quanta meter, and expressed in Einstein $\mathrm{m}^{-2} \mathrm{~s}^{-1}$ PAR $\left(1\right.$ Ein $\mathrm{m}^{-2} \mathrm{~s}^{-1} \mathrm{PAR} \equiv 1 \mathrm{Mol}$ quanta $\mathrm{m}^{-2}$ $\mathrm{s}^{-1}$ in the waveband 400 to $700 \mathrm{~nm}$ ). Daylength regime and lightbreak treatments were provided by Microflash timers.

The response to a given treatment was estimated by determining the percentage of plants per Petri dish that had become fertile (Fig. 1). A plant was considered fertile when at least one gametangium had appeared.
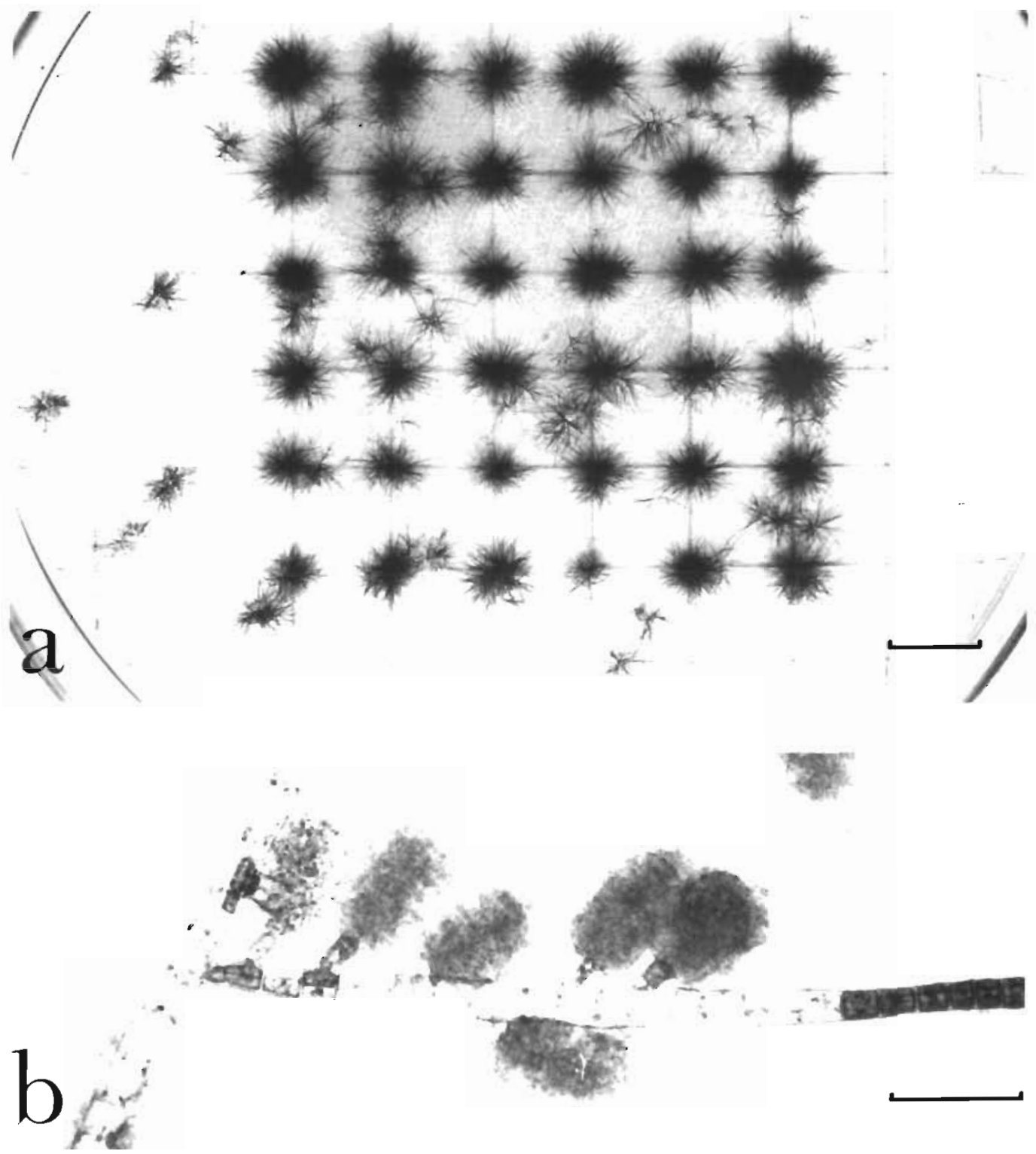

Fig. 1. Sphacelaria rigidula. (a) Male gametophytes attached to glass microfibre filter paper on the bottom a Petri dish cultured for $60 \mathrm{~d}$ at $12^{\circ} \mathrm{C}, 16: \overline{8}, 20 \mu$ Ein $\mathrm{m}^{-2} \mathrm{~s}^{-1}$; scale bar: $10 \mathrm{~mm}$. (b) Male gametophyte cultured for $81 \mathrm{~d}$ at $12{ }^{\circ} \mathrm{C}, 24: \overline{0}, 2.5 \mu$ Ein $\mathrm{m}^{-2} \mathrm{~s}^{-1}$; most of the axial cells die after having produced a gametangium; scale bar: $100 \mu \mathrm{m}$ 
Differences in total numbers of gametangia per plant were not taken into account. Confidence limits were derived from tables for percentages (Sokal and Rohlf, 1973; see for instance Lüning, 1981b).

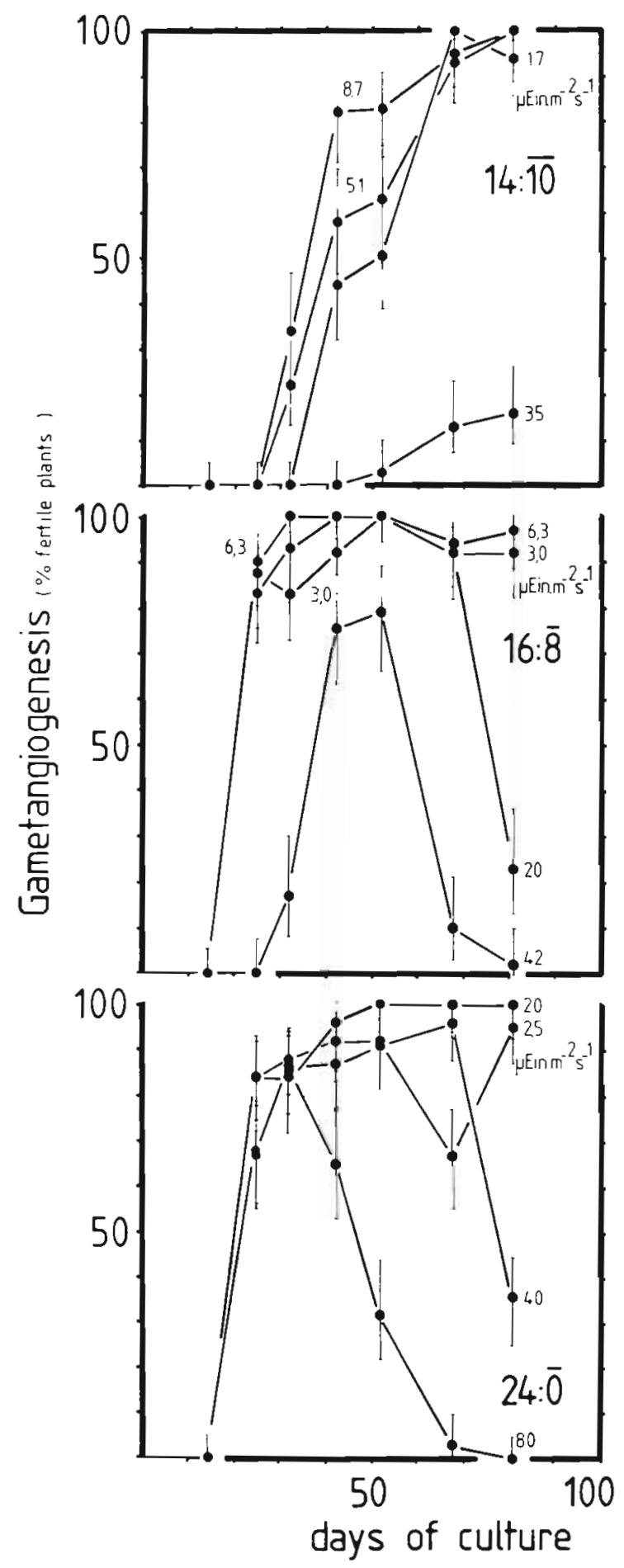

Fig. 2. Sphacelaria rigidula. Formation of gametangia at various daylength and irradiance condition. Vertical bars: $95 \%$ confidence limits ( $n=46-79$ )

\section{RESULTS}

Effects of daylength and irradiance on gametangia formation

To examine the effect of daylength and irradiance on the formation of gametangia, male gametophytes were cultured in light-dark regimes of $8: \overline{16}, 12: \overline{12}, 14: \overline{10}$, $16: \overline{8}$ and $24: \overline{0}$ under irradiances varying between 2.5 and $82 \mu$ Ein $\mathrm{m}^{-2} \mathrm{~s}^{-1}$. The percentage of fertile plants was then determined at regular intervals (Fig. 2).

In light-dark regimes with less than $14 \mathrm{~h}$ of light $\mathrm{d}^{-1}$, gametangia never formed, not even after several months. Gametangia appeared first in regimes of the longest photoperiods $(24: \overline{0}$ and $16: \overline{8})$; their formation was delayed near the critical daylength $(14: \overline{10})$, especially at higher irradiance. In the $16: \overline{8}$ and $24: \overline{0}$ regimes the number of fertile plants decreased after some time, especially at higher irradiance levels. This was caused by the fact that the gametangia sporulated rapidly, leaving only stalks and empty gametangia on the plants. Thereafter vigourous vegetative growth started, without any further formation of gametangia. At very low irradiance the plants hardly survived the process of fertilisation; after having produced a gametangial branch, most of the thallus-cells died and practically no new growth occurred (Fig. 1b).

\section{Effect of a light break on gametangia formation}

The effect of a 30 min light break, introduced at various times during the long dark period $(16 \mathrm{~h})$, is shown in Fig. 3. The percentage of fertile plants was

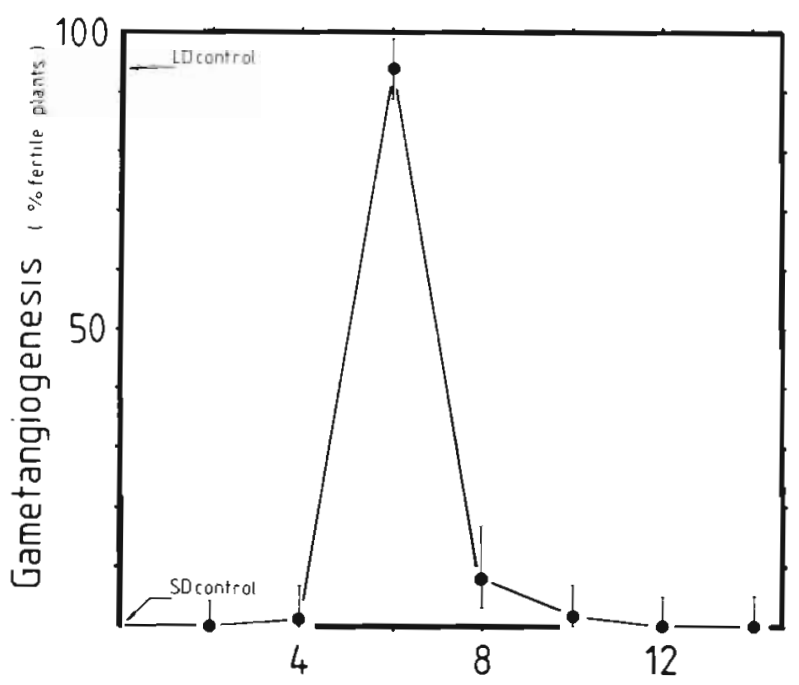

Time of light break after start of dark period (hours)

Fig. 3. Sphacelaria rigidula. Influence of light breaks on the formation of gametangia. Irradiance during light break and during main light period $(8 \mathrm{~h})$ was $20 \mu$ Ein $\mathrm{m}^{-2} \mathrm{~s}^{-1}$. Vertical bars: $95 \%$ confidence limits $(n=72)$ 
determined at regular intervals for up to $60 \mathrm{~d}$. Maximal response (Fig. 3) was reached within $40 \mathrm{~d}$. Interruption of the dark period at the 6th hour of darkness induced gametangia in $94 \%$ of the plants. Light breaks at other moments of the night were far less effective or totally ineffective.

\section{Effect of limited numbers of long-day cycles on gametangia formation}

Whether gametangia could be induced by a limited number of long-day cycles was investigated by placing cultures in a long-day regime $(24: \overline{0})$ for 1 to $12 \mathrm{~d}$ before transfer to a non-inductive short-day regime $(8: \overline{16})$. After $10 \mathrm{~d}$, gametangia were not yet recognizable; after $15 \mathrm{~d}$ they were present in all cultures kept under long-day conditions for more than 8 d. Fig. 4 shows, for

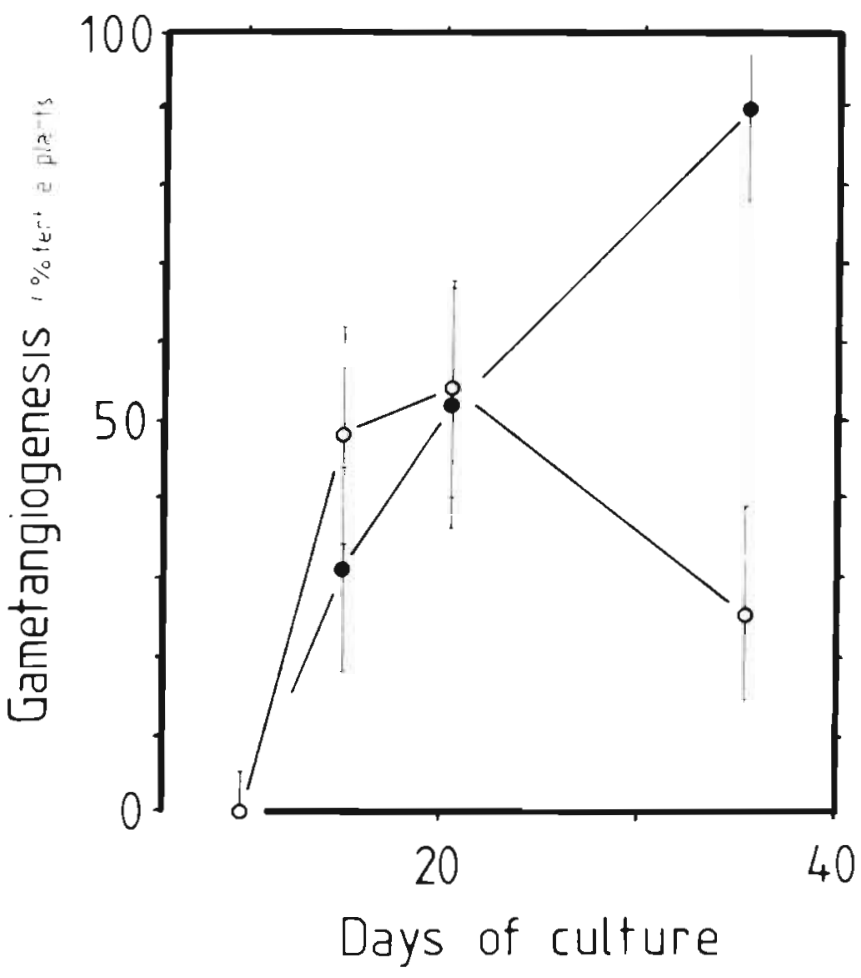

Fig. 4. Sphacelaria rigidula. Induction of gametangia in plants kept under long-day conditions $\left(24: \overline{0}, 13 \mu \mathrm{Ein}^{-2} \mathrm{~s}^{-1}\right)$ for $10 \mathrm{~d}_{\text {; }}$ the plants were thereafter transferred to short-day conditions $\left(8: \overline{16}, 40 \mu\right.$ Ein $\left.\mathrm{m}^{-2} \mathrm{~s}^{-1}\right)(0-0)$. Long-day control

$(\bullet-$ ) Vertical bars: $95 \%$ confidence limits $(n=42-52)$

plants that had undergone 10 inductive long-day cycles, that the number of plants with gametangia was similar to that in the long-day control until the 21st day but subsequently decreased. Evidently, the plants remained in the induced state for only a very short time.

\section{DISCUSSION}

In male gametophytes of Sphacelaria rigidula the formation of gametangia is a photoperiodic long-day response. Gametangia were formed when the long dark period in a $24 \mathrm{~h}$ cycle was interrupted by a short light break. This is the first proof for algae that a longday response can be induced by light-break treatment. In higher plants light-break treatments are effective in many, but not in all long-day plants. In general, longday plants are less sensitive to light breaks than shortday plants (Vince-Prue, 1975). The moment of maximal sensitivity to light breaks can differ greatly between different species. Often, the phase of maximum effectiveness is the middle of the night, but in many plants this phase lies earlier or later (Vince-Prue, 1975). In Sphacelaria it lies before the middle of the night, between the 4 th and the 8 th hour of darkness. In algae with a short-day response the phase of maximal sensitivity also varies for different species. In the red alga Acrochaetium asparagopsis there are even 2 separate sensitive phases - one after about $2 \mathrm{~h}$, the other after $10 \mathrm{~h}$ of darkness (Abdel-Rahman, 1982). So far, 2 different pigment systems have been found in the photoperiodic short-day responses of brown algae. In Ascophyllum nodosum the mediating pigment possibly is phytochrome (Terry and Moss, 1980). In Scytosiphon lomentaria a blue light absorbing pigment without absorption in the red and far-red part of the spectrum is involved (Dring and Lüning, 1975). For this pigment no photoreversibility could be demonstrated. It will be interesting to determine the action spectrum of the long-day response in Sphacelaria rigidula.

The critical daylength of ca. $13 \mathrm{~h}$ is not in accordance with earlier reports. Van den Hoek and Flinterman (1968) found male gametangia in a $12: \overline{12}$ regime but they did not indicate their abundance or the time needed for their formation. Colyn and van den Hoek (1971) found female gametangia in the $12: \overline{12}$ regime and state that, in this regime, the gametangia appeared later than in regimes with longer light periods. For the male gametangia their results were inconclusive. These differences in the estimation of the critical daylength may be caused by differences in the duration of the experiments, though the total duration of our experiments exceeded the time that was sufficient for appearance of the female gametangia (Colyn and van den Hoek, 1971). Probably, different estimates of the critical daylength can be obtained, depending on the condition of the plants used for experiments.

The formation of gametangia was influenced by irradiance and was suboptimal at high irradiances, especially near the critical daylength. At high irradiance in regimes with very long days the production of gametangia stopped after some time. The plants 
continued vigourous vegetative growth, but formed no new gametangia, These observations suggest that vegetative growth may counteract the process of gametangiogenesis.

In Sphacelaria gametangia could be 'induced' by a relatively short exposure to long-day cycles, but the plants remained in the induced state for only a very short time. For algae, the concept of 'induction' should be applied with care. It is evident in higher plants that 'induction' takes place, as perception of the environmental stimulus and the reaction to this stimulus may occur in different parts of the plant (leaf and apex, respectively). In algae such as Sphacelaria rigidula the sites of perception and response are spatially probably not so distinctly separated. Whether 'induction' takes place may depend on the stage of development that is chosen to measure the response. In Sphacelaria this stage was the appearance of gametangia. The gametangia develop on top of short ( 1 to 2 celled) laterals and a young gametangium is not recognizable in its initial stage of development. The results suggest that long-day conditions are required for formation of a gametangial branch. Thereafter, the gametangium may ripen and sporulate also in non-inducing daylength conditions.

Acknowledgements. We wish to thank Professor Dr. C. van den Hoek, Professor Dr. Ir. P. J. C. Kuiper and Mr. B. Veldstra for their help and comments in the course of this work. The investigations were supported by the Foundation for Fundamental Biological Research (BION), which is subsidized by the Netherlands Organisation for the Advancement of Pure Research (ZWO).

\section{LITERATURE CITED}

Abdel-Rahman, M. H. (1982). Photopériodisme chez Acrochaetium asparagopsis (Rhodophycées, Acrochaetiales). Influence de l'interruption de la nyctiperiode, par un éclairement blanc ou monochromatique, sur la formation des tétrasporocystes C. R. Acad. Sci. Paris 294, Ser. III: 389-392

Breeman, A. M. (1979). The life-history and its environmental regulation in the subtidal red alga Acrosymphyton purpuriferum (J. Ag.) Sjöst thesis, Groningen

Colyn, F., van den Hoek, C. (1971). The life-history of Sphacelaria furcigera Kütz. (Phaeophyceae) II. The influence of daylength and temperature on sexual and vegetative reproduction. Nova Hedwigia 21: 899-922

Dring, M. J. (1970). Photoperiodic effects in microorganisms. In: Halldal, P. (ed.) Photobiology of microorganisms. Wiley, London, p. 345-368

Dring, M. J., Lüning, K. (1975). A photoperiodic response mediated by blue light in the brown alga Scytosiphon lomentaria. Planta 125: 25-32

Hoek, C. van den, Flinterman, A. (1968). The life-history of Sphacelaria furcigera Kütz. (Phaeophyceae). Blumea 16: 193-242

Lüning, K. (1980). Control of algal life-history by daylength and temperature. In: Price, J. H., Irvine, D. E. G., Farnham, W. F. (ed.) The shore environment, Vol. 2, Ecosystems. Academic Press, London, p. 915-945

Lüning, K. (1981a). Photomorphogenesis of reproduction in marine macroalgae. Ber. dt. bot. Ges. 94: 401-417

Lüning, K. (1981b). Egg release in gametophytes of Laminaria saccharina: induction by darkness and inhibition by blue light and UV. Br. Phycol. J. 16: 379-393

Prud'homme van Reine, W. F. (1982). A taxonomic revision of the European Sphacelariaceae (Sphacelariales, Phaeophyceae). Brill, Leiden, University Press, Leiden

Sokal, R. R., Rohlf, F. J. (1973). Introduction to biostatistics. Freeman Comp., San Francisco

Terry, L. A., Moss, B. L. (1980). The effect of photoperiod on receptacle initiation in Ascophyllum nodosum (L.) Le Jol. Br. Phycol. J. 15: 291-301

Vince-Prue, D. (1975). Photoperiodism in plants. McGraw Hill, Maidenhead 